\title{
A Clash between IT Giants and the Changing Face of International Law: The Samsung vs. Apple Litigation and Its Jurisdictional Implications
}

Jaemin Lee *

There has been a sudden surge in simultaneous legal disputes between Samsung and Apple in domestic courts of multiple States since 2011 concerning patent infringements involving their new digital products. The intensity of these confrontations between the two digital giants has come to exert significant influence over the lives of many people all over the world. In a sense, they are not competing to protect or increase the market share in a given domestic market, as other large corporations usually do; rather, they are now competing in a single, integrated global digital market where borders and boundaries have virtually disappeared. The emergence of the dominant digital entities is a showcase example of the increasing role of the MNCs in the international community, an issue that has already attracted a significant amount of attention from scholars of international law. At the same time, the unprecedented clash between the two corporations in multiple jurisdictions also raises an important issue of how conventional jurisdictional principles under international law are and will be implicated in this regard.

\section{Keywords}

Prescriptive Jurisdiction, Enforcement Jurisdiction, Municipal Courts, Multinational Corporations, Patent Infringement, IPRs, CSR

* Professor of Law at Hanyang University School of Law. LL.B./LL.M./Ph.D.(Seoul N.U.), J.D.(Boston College), LL.M.(Georgetown). The author may be contacted at: jaemin@hanyang.ac.kr/Address: School of Law, Hanyang University, 17 Haengdang-dong, Sungdong-gu, Seoul 133-791 Korea. 


\section{Introduction}

A new digital revolution is in full gear. Smartphones and tablet PCs have conquered the world in a very short timeframe. ${ }^{1}$ Millions of people use smartphones or tablet PCs and subscribe various programs provided by the smartphones in affiliation with relevant service providers. ${ }^{2}$ Smartphones and tablet PCs have enabled people to be wired, literally, all the time. ${ }^{3}$ These technologies have become an integral part of our daily lives and are significantly changing the way we live. 4 Social network services have changed the method people communicate with each other, the immense potential of which has become evident in recent political elections. Smartphones and tablet PCs have become ubiquitous throughout the world market. These products are advertised, sold and serviced globally at the same time and with the same conditions.

The rise of smartphones has also brought with it a substantial increase in litigation. Since early 2011, legal battles between Samsung and Apple have been plaguing courts in various countries, with the two corporations showing no signs of slowing down. Together, the intensity and frequency of disputes have been elevated with each new lawsuit. The Samsung-Apple disputes have received a great deal of attention from many countries due to the number of jurisdictions involved and the direct effect the litigation has on consumers. In other words, the attention has been largely involved a general curiosity coupled with a practical purchasing-level problem. On the one hand, people are curious to watch epic battles between two global IT giants, while, on the other hand, the result of the litigation may end up prohibiting or limiting the sales of products produced in their in the respective markets.

At the same time, the spike of international litigation has presented a new momentum to evaluate the changing nature of the international community and the

1 Julius Genachowski, Remarks at the GSMA Mobile World Congress in Barcelona, Spain (Feb. 27, 2012), available at http://www.fcc.gov/document/chairman-genachowskis-remarks-gsma-mobile-world-congress (last visited on Apr. 30, 2012).

2 This phenomenon is particularly visible in Korea. The statistics released on October 31, 2011, by the Korea Communications Commission, describe the virtual explosion of smartphone subscriptions in Korea. As of October 31, 2011, the total number of smartphone users in Korea exceeded 20 million. Four out of ten Koreans and eight out of ten economically active populations in Korea are currently using smartphones. More remarkable is the rate of surge of those subscriptions: the 20 million mark has been reached in just 23 months since the smartphone was first introduced in the Korean market in November 2009. See Sung-won Shim, South Korea Smart Phone Subscribers Exceed 20 Million, REUTERS (Oct. 31, 2011), available at http://www.reuters.com/article/2011/10/30/us-koreasmartphone-idUSTRE79T0WV20111030 (last visited on Apr. 30, 2012).

3 Steve Lohr, Smartphone Rises Fast from Gadget to Necessity, N.Y. Times (June 9, 2009), available at http://www.nytimes.com/2009/06/10/technology/10phone.html (last visited on Apr. 30, 2012).

4 Supra note 1. 
resulting impact on international law. The issue of private actors in international law and its legal implications has been discussed mainly in the context of regulating private security companies participating in military activities and enhancing corporate social responsibilities ("CSR") for multinational corporations ("MNCs"). But rarely has the issue of emerging 'digital authority' been discussed in the context of international law. The beginning of the digital age may inevitably bring the advent of the digital authority. We are all aware of how even a brief interruption of internet service can agitate our frenzied need to get our 'digital dose' for the day. If there are corporations that dominate the global digital market, such as Samsung and Apple, their impact will be significant as evidenced by their recent legal disputes.

This article aims to analyze this structural issue relating to or arising from the Samsung-Apple litigation from an international legal perspective. This article addresses these disputes not merely from an intellectual property rights perspective; rather, it analyzes these disputes to elicit a systemic implication for international law. This article is composed of six parts including Introduction (Part I) and Conclusion (Part VI). Part II will discuss the recent surge of litigations between Samsung and Apple in multiple jurisdictions over alleged patent infringements. Part III will then look into increasing roles being played by private entities in the international community and the resulting implications on the international legal plane. Based on these discussions, Part IV will explore the unique aspects of the simultaneous clashes between multinational digital giants in many jurisdictions and its effect on the jurisprudence of international law. Part $\mathrm{V}$ will present the author's idea of exploring new paradigm to address this situation. The Samsung-Apple litigation has presented a timely occasion to examine these issues set forth in respective parts.

\section{The Surge of Litigation between Samsung and Apple}

The smartphone and tablet PC segments are among the fastest-growing markets in the technology sector. 5 Samsung and Apple dominate the global market of smartphones and tablet PCs. In addition to the fierce competition, they are also involved in all-out legal battles in many jurisdictions involving claims of the IPR infringement related to their digital products.

The legal confrontation between Apple and Samsung began in April 2011, when

5 See Apple and Samsung Chiefs to Meet to Sort Patent Dispute, BBC NEWS (Apr. 18, 2012), available at http://www.bbc.co.uk/news/business-17751806 (last visited on Apr. 30, 2012). 
Apple sued Samsung for patent infringement. Apple claimed that Samsung had copied "the look and feel" of its iPhone and iPad in the production of its flagship Galaxy S line of devices. ${ }^{6}$ Samsung immediately responded with its own countersuit against Apple for the infringement of five key patents relating to wireless networking technologies.7 As of this writing, Apple and Samsung are mounting their legal battles in 30 ongoing lawsuits spanning over twelve different countries and four continents. 8

Existing conventions on the IPRs impose specific obligations on the State parties to adopt administrative and judicial mechanism to deal with the IPR infringements. One of the key elements of the obligation is to adopt a judicial remedy for the victim of the IPR infringement. In addition, the Agreement on Trade Related Intellectual Property Rights ("TRIPs") of the World Trade Organization ("WTO") sets forth a specific obligation to set up administrative, civil and criminal proceedings to deal with IPR infringement. 9 In this case, an aggrieved corporation asks a domestic or foreign court or administrative agency to (1) the expulsion of the product from the commercial chain of the market, and (2) cessation of further entry of the product into the market.10

As the largest multinational corporations with branch offices and sales organizations in every corner of the world, Samsung and Apple are subject to the jurisdictions of many countries.11 It was relatively easy to file complaints against each other in various

6 Joseph Cotterill, Apple Sues Samsung over iPad Patents, Financial Times (Apr. 19, 2011), available at http://ftalphaville.ft.com/thecut/2011/04/19/549556/apple-sues-samsung-over-ipad-patents / (last visited on Apr. 30, 2012).

7 See Samsung Countersues Apple on iPhone and iPad Patents, Reuters, republished at N.Y. Times (Apr. 23, 2011), available at http://www.nytimes.com/2011/04/23/technology/23samsung.html?_r=1 (last visited on Apr. 30, 2012). It reads: "Samsung said the fresh suit, filed at a Seoul court in response to the previous Apple claims, covers three utility patents and involves methods of displaying data, the user interface, and short text messages." See also Miyoung Kim, Samsung Files Fresh Lawsuit against Apple in South Korea, ReUTERs (Mar. 7, 2012), available at http://www.reuters.com/article/2012/03/07/us-samsung-apple-lawsuit-idUSTRE8260F420120307; Christian Oliver, Samsung Sues Apple for Infringement, FinanCial Times (Mar. 20, 2012), available at http://www.ft.com/intl/cms/s/ 2/c5eb3d38-6cb7-11e0-83fe-00144feab49a.html\#axzz1semBoDyW; Christian Oliver, Fast Follower Leads the Way, FinANCial Times (Mar. 20, 2012), available at http://www.ft.com/intl/cms/s/0/7b622220-6e57-11e1-b98d00144feab49a.html\#axzz1semBoDyW (all last visited on Apr. 30, 2012).

8 Chloe Albanesius, Every Place Samsung and Apple Are Suing Each Other, PCMAG.Com, available at http://www.pcmag.com/article2/0,2817,2392920,00.asp (last visited on Apr. 30, 2012); Kim, supra note 7. TRIPs Agreement Pt. III, secs. 2, 3 \& 5 .

10 Id.

11 By way of example, to establish specific jurisdiction, the Due Process Clause of the Fourteenth Amendment of the U.S. Constitution is interpreted to require that a plaintiff show that the defendant has at least minimum contacts with the forum State such that maintenance of the suit in the does not offend "traditional notions of fair play and substantial justice." See International Shoe Co. v. Washington Case, 326 U.S. 310, 316, (1945). Put differently, claims can be brought to the domicile of the corporation or the State where any branch is located and has sufficient links to the act causing the damage. See also Olivier De Schutter, The Accountability of Multinationals for Human Rights Violations in European Law, in Non-STATE Actors AND HuMAN Rights 258-260 (P. Alston ed. 2005). 
domestic courts. Thus, when Apple sued Samsung for patent infringement, Samsung found it easy to respond in kind with its own legal actions. A tit-for-tat thus ensued.

The disputes center around the IPR infringements in general and patent infringement in particular. The allegations and findings of the IPR infringement are currently major sources of dispute among business entities in many countries. In fact, rapid globalization has increasingly packed the dockets of domestic courts with disputes involving international transactions. 12 The disputes between Samsung and Apple in many jurisdictions may reflect this general tendency in the global community. Perhaps more crucially, however, these disputes also provide a good opportunity to notice the changing paradigm of the international community and to explore the need to examine new concepts of international law.

\section{The Increasing Role of Private Entities on the International Legal Plane}

Throughout the world, private entities play an increasingly important role, which has been traditionally reserved to and administered by government. 13 This new trend of 'outsourcing' or 'privatization' of governmental functions presents a new set of legal issues. One of the most vivid examples in this regard is the surge of private military corporations ("PMCs") that perform the duties of regular armed forces in many respects. 14

A similar trend is being observed in economic sectors, as well. Moody's Investors Service, Standard \& Poor's, and Fitch Ratings are the troika of U.S.-based global credit rating agencies. The 2008 global financial crisis and ensuing events have evidenced the significant influence these agencies possess vis-à-vis governments as well as commercial entities. 15 The virtual authority wielded by these agencies has even reached a point

12 Mary O'Connell, Enforcement and the Success of International Environmental Law, 3 IND. J. GLOBAL LeGAL STUD. (1995). See also Christopher Whytock, Domestic Courts and Global Governance, 84 TuL. L. REv. 67, 74 (2009).

13 John Yoo, Force Rules: U.N. Reform and Intervention, 6 CHI. J. INT' L L. 647 (2006).

14 Jeffrey Addicott, Contractors on the "Battlefield:" Providing Adequate Protection, Anti-Terrorism Training and Personnel Recovery for Civilian Contractors Accompanying the Military in Combat and Contingency Operations, 28 Hous. J. INT'L L. 323, 325(2006). Blackwater Inc. is perhaps is the most well-known PMC due to its controversial activities in the course of offering security service to officials and military personnel in Iraq and Afghanistan. At the same time, commercial entities also increasingly purchase the service of PMCs in many parts of the world. For instance, Protection Vessels International, Ltd. is a PMC that provides protection and escort service to merchant ships that sail through pirate-infested Gulf of Aden.

15 Sovereign States are directly affected by the change of ratings by these global credit rating agencies, since the adjustment of ratings would translate to "an increase or decrease of national cost of financing." Consequently, a 
where private entities are guiding governments to design and implement financial or economic policies. 16

Similarly, multinational corporations ("MNCs")17 have been accumulating influence and assuming more important roles in the international community, which has posed various novel issues for international law.18 For a long time, the MNCs operated outside of international law. ${ }^{19}$ However, they have been increasingly subject to international law, e.g., with respect to human rights, labor or environmental protection in the context of Corporate Social Responsibility ("CSR"). ${ }^{20}$ At the same time, the MNCs not only remain as mere rule-takers, but they have also become active users of international law. 21 International investment dispute settlement proceedings, e.g., have accepted the MNCs as a new, independent subject of international law.22

downgrade of a sovereign State is usually met with a harsh response from the government involved. Upon the Standard \& Poor's downgrade of the U.S. sovereign rating in August 2011, President Obama harshly criticized the agency for its alleged failure to consider all relevant factors appropriately, declaring that regardless of the downgrade "the United States will always be an AAA country." See Jena McGregor, President Obama talks S\&P downgrade-finally, WASH. PoST (Aug. 8, 2011), available at http://www.washingtonpost.com/blogs/post-leadership/post/president-obamatalks-sandp-downgrade-finally/2011/04/01/gIQA7gVs2I_blog.html (last visited on Apr. 30, 2012).

16 The Statement of Standard \& Poor's upon its January 13, 2012 downgrade of the certain European Union States reads: "Today's...actions are primarily driven by our assessment that the policy initiatives...taken by European policymakers...may be insufficient to fully address ongoing systemic stresses in the Eurozone." See Standard \& Poor's Takes Various Rating Actions on 16 Eurozone Sovereign Governments, Standard \& Poor's Rating SERVICES, (Jan. 13, 2012), available at http://www.standardandpoors.com/ratings/articles/en/us/?articleType=HTML\&assetID= 1245327294763 (last visited on Apr. 30, 2012). This Statement of the agency arguably shows that the downgrade is based on the agency's overall assessment of the financial policies of 16 Eurozone governments.

17 For details on the definition of the MNCs, see Peter Muchlinski, Multinational EnterpRises and the LaW 12-15 (1995). Generally, the term, MNC or TNC refers to a corporation with affiliated business operations in more than one country. The number of the MNCs has grown steadily over the years. According to some experts, currently, there are more than $63,000 \mathrm{MNCs}$ with 821,000 subsidiaries scattered all over the world, employing 90 million people, and taking up as much as $20 \%$ of the global GDP. See Medard Gabel \& Henry Bruner, Global Inc.: AN Atlas of The Multinational CoRPorations 7 (2003).

18 Sean Murphy, Principles of International LaW 62 (2006).

19 John Noyes et AL., InTERnational LaW Stories 333-335 (2007).

20 This is indeed a significant development given the fact that for a long time the legal guidance provided by the public international law (except in the investment dispute context) has been the issue of the nationality of the MNCs. See Barcelona Traction, Light and Power Co. Case (Belg. v. Spain), 1970 I.C.J. 3, 168 (Feb. 5).

21 Supra note 18, at 62-63.

22 The international investment dispute settlement proceedings are usually introduced as a result of Bilateral Investment Treaties ("BITs") or Free Trade Agreements ("FTAs"). As of the end of 2008, the total number of reported investment disputes arising from the BITs or the FTAs has reached 317, involving 77 governments. See United Nations Conference on Trade and Development ( "UNCTAD"), Latest Developments in Investor - State Dispute Settlement, Doc. No. NCTAD/WEB/DIAE/LA/2010/3 (New York \& Geneva 2010), at 1. See also Susan Franck, The Legitimacy Crisis in Investment Treaty Arbitration: Privatizing Public International Law Through Inconsistent Decisions, 73 Fordham L. Rev. 1521 (2005); Stanimir Alexandrov, Breaches of Contract and Breaches of Treaty -The Jurisdiction of Treaty-based Arbitration Tribunals to Decide Breach of Contract Claims in SGS v. Pakistan and SGS v. Philippines, 5 J. World Investment \& TRAde 555 (2004). 
Against this backdrop, the international community has become more vigilant when it comes to the activities and regulation of such entities. Also, previously inchoate legal norms are getting firmer in a wide range of areas involving the activities and regulation of the MNCs. 23 In this sense, it is hardly surprising the global impact MNCs like Samsung and Apple have on certain aspects of international law.

Notwithstanding, the discussions so far have mainly focused on how to regulate the behavior of the MNCs in the globalized world so that they can be more responsible in the overall operation of their businesses, e.g., abiding by human rights and labor standards. In contrast, discussions related to the MNCs' structural nature have been much rarer. Examples of such structural issues include coordination (or noncoordination) of jurisdiction among States over the MNCs because the recent SamsungApple clashes in many jurisdictions showcase the inherent limitations of the conventional jurisdictional principles of international law. These structural issues have surfaced due to the unique traits of Samsung and Apple. As they operate in so many jurisdictions, the way they exercise their influence is arguably different from the conventional way other MNCs do. As the international community is standing at the the doorstep of a new digital age, it is now necessary to analyze these 'structural' issues.

\section{The Clash between Multinational Digital Giants and Its Effect}

The litigation between Samsung and Apple is not the typical dispute between large corporations. Rather, both in terms of the scope and effect, the Samsung-Apple disputes can be distinguished from other disputes involving the MNCs.

UN Secretary-General Kofi Annan introduced the Global Compact in 1999, which set forth ten principles for the MNCs mainly in the area of human rights, labor and environmental protection areas. Although this document is not legally binding, it does offer an important guideline for the regulation of the MNCs by the international community in accordance with international law. See Ralph Steinhardt, Corporate Responsibility and the International Law of Human Rights: The New Lex Mercatoria, in Alston, supra note 11, at 206. For details, see UN Global Compact website, available at http://www.unglobalcompact.org. The Global Compact is the culmination of the previous work of the UN to discuss and adopt codes of conducts for the MNCs. For the discussions on the pre-Global Compact projects undertaken by the UN, see August Reinisch, The Changing International Legal Framework for Dealing with Non-State Actors, in Alston supra note 11. Similar activities have also taken place in the Organization for Economic Co-operation and Development ("OECD"). The OECD adopted the Guidelines for Multinational Enterprises in 1976 which was revised in 2000. See OECD, the Decision of the OECD Council on the OECD Guidelines for Multinational Enterprises, available at http://www.oecd.org (all last visited on Apr. 30, 2012). 


\section{A. Unique Traits of Dominant Digital Corporations}

Samsung and Apple possess and exercise unique influence in the global market.24 Essentially, these two corporations produce digital devices that allow people to communicate with each other and participate in various kinds of social activities. While there exists a traditional phone function, it is almost incidental; their devices could be more properly characterized as multi-functional personal networking equipment, 25 or what Thomas Friedman predicted about twelve years ago. ${ }^{26}$ Considering their market share, Samsung and Apple effectively constitute a duopoly in the production and sales of their respective devices. 27

\section{Literal Omnipresence}

The Samsung-Apple disputes have reminded us of the literal omnipresence of the two digital giants. They maintain branch offices and sales outlets in almost all countries in the world, and sell and service their products in thousands of markets. In fact, to them there is one single global market; traditional borders are meaningless from their perspective. No other MNCs are 'omnipresent' as the way these digital giants areviewing the global market as a single unit.28 Many can remember the simultaneous release of a new item by Apple and the long waiting lines all over the world.29 Consumers of all regions use the same products with exactly same specifications and download the same application programs. 30 Neither product nor vendor organizes and

24 For the definition of the MNCs, see Muchlinski, supra note 17.

25 For the brief dictionary definition of smartphones, see Merriam-Webster On-Line Dictionary available at http://www.merriam-webster.com/dictionary/smartphone; PC Magazine Encyclopedia, available at http://www.pcmag.com/encyclopedia_term/0,2542,t=Smartphone\&i=51537,00.asp (last visited on Apr. 30, 2012).

26 Thomas Friedman, The Lexus and The Olive Tree 67 (2000). It reads: "The next stage, the one that will characterize the early twenty-first century, is when everyone will have access to high-speed, broadband Internet communications right in their home or office or handheld notepad or beeper."

27 Tero Kuittinen, Now or Never, HTC, FoRBES (Mar. 30, 2012), available at http://www.forbes.com/sites/terokuittinen/ 2012/03/30/now-or-never-htc/ (last visited on Apr. 30, 2012). See also Wayne Lam, Apple Retakes Smartphone Lead in Q4; Samsung Grabs Top Spot for Full-Year 2011, ISUPPLY (Jan. 26, 2012), available at http://www.isuppli.com/ Mobile-and-Wireless-Communications/News/Pages/Apple-Retakes-Smartphone-Lead-in-Q4;Samsung-Grabs-Top-Spot-forFull-Year-2011.aspx; MSN Money, Apple Regains Top Spot in Smartphone Market (Jan. 31, 2012), available at http://money.msn.com/top-stocks/post.aspx?post=eea5f5fc-5dd5-4a7d-9a81-99b399c3ffb0 (all last visited on Apr. 30, 2012).

28 For example, the two companies' recent advertisements announced the simultaneous release and provision of the new products in the global markets. See Samsung Offers Premium Suite Software Upgrade for GALAXY Note Users, SAMSUNG, available at http://www.samsung.com/us/news/newsRead.do?news_seq=20145\&page=2\&gltype=globalnews. (The company announces the provision of new service product on a worldwide basis); New iPad Arrives in South Korea \& 11 Additional Countries This Week, APPLE, available at http://www.apple.com/pr/library/2012/04/16NewiPad-Arrives-in-South-Korea-11-Additional-Countries-This-Week.html (all last visited on Apr. 30, 2012). 
mobilizes the global market this way.

This unprecedented ubiquitousness combined with the global single-market nature may have fueled the fierce litigation between Samsung and Apple across the world. Having a 'global jurisdiction' to resolve disputes in the global smartphone/tablet PC market may be necessary to resolve this unique situation.

\section{Overwhelming Digital Authority}

Owning a smartphone an/or a table PC is necessary to participate in the new digital community. People are pressed, in a sense, to purchase these products to keep up with the changing digital environment. 31 They are eager to provide information and connect to the new outer world.32 Considering their overwhelming market share in the sale of such products and related application services, Samsung and Apple have become magnets of crucial information and sources of significant influence over the daily lives of people. 33

The fact that ordinary people have no choice but to stand idly by and watch the intensifying legal battles between the two giants, is evidence of public's lack of power. As far as the litigation is concerned, the governments may not seem that much different on this score. Samsung and Apple would sometimes carry more weight than sovereign States; their decisions affect the peoples' lives more directly than governmental policies. 34 Assuming that the influence wielded by the MNCs are more controversial with respect to developing countries,35 Samsung and Apples dominance in the digital marketplace should further stand out concerning consumers and markets of developing States.

31 See New Features with Software Update, available at http://www.samsung.com/us/mobile/galaxy-tab/GTP7510MAYXAB-features; Apps by Apple, available at http://www.apple.com/ipad/from-the-app-store/apps-by-apple (all last visited on Apr. 30, 2012).

32 Id.

33 Connie Guglielmo, Congress Has More Questions Over Apple iPhone Privacy, ForBes (Mar. 14, 2012), available at http://www.forbes.com/sites/connieguglielmo/2012/03/14/congress-has-more-questions-over-apple-iphone-privacy (last visited on Apr. 30, 2012).

34 See Theodore Moran, How Does FDI Affect Host Country Development?: Using Industry Case Studies to Make Reliable Generalizations, in Does Foreign Direct Investment Promote Development? 283-309 (T. Moran et al, eds. 2005); Why Does Samsung Ignore the Law and Hinder Government's Legitimate Probe?, Chosun DaILY (Mar. 20, 2012), available at http://news.chosun.com/site/data/html_dir/2012/03/19/2012031901624.html (available only in Korean) (last visited on Apr. 30, 2012).

35 Joseph Stiglitz, Regulating Multinational Corporations: Towards Principles of Cross-Border Legal Frameworks in a Globalized World Balancing Rights with Responsibilities, 23 AM. U. INT' L L. Rev. 451, 453 (2007-2008). 


\section{B. Unique Traits of Digital Products}

\section{Non-Amenable to Territorial Confinement}

The digital devices manufactured and sold by Samsung and Apple are unique in that they are not amenable to traditional territorial confinement. 36 Their devices provide access to unlimited information at any time. ${ }^{37}$ The advent of the internet has permitted this phenomenon, but the existing internet service has still been tied to a physical location, as a person needs a computer and specified connection (either thorough cables or wireless stations). This existing service is not even comparable to the universal access that the smartphones and tablet PCs offer. Although these digital products physically exist in a particular location at a particular point in time, they are consumed on a global basis outside of traditional physical boundaries. 38

The on-the-spot connection provided by the new digital products has largely liberated us from the traditional physical limitations and has enabled multitasking from any location or at any time. ${ }^{39}$ Thus, the traditional concept of territorial limitation bears little relevance to digital products and the social phenomenon created by them.

\section{Prone to Patent Litigation}

Compared to conventional consumer products, digital products are more prone to patent disputes due to the fast development of information technology and related parts. ${ }^{40}$ Fast technological development and ensuing complex patent registration are a phenomenon being observed in all economic sectors. No sector, however, can match the lightening speed and complexities being observed in the information technology sector. Just consider cell phones used a decade ago as compared to today's current models - a true transformation in all respects. It is even questionable whether smartphones we carry now can still be categorized as a traditional cell phone.41

Such being the case, the advent of the new digital age naturally brings with it new rounds of patent litigation. This surge has elevated the importance of domestic

\footnotetext{
36 In this regard, these digital products are different from other major consumer items such as automobiles, household appliances, or other electronic devices. These products also play an important role in the modern society, but they are still based on and geared toward traditional territorial limits.

37 The introduction of iCloud has further cemented this liberation from the physical confinement. See What is iCloud?, APPLE, available at http://www.apple.com/icloud/what-is.html (last visited on Apr. 30, 2012).

38 In sum, this dimension is what is commonly called as 'cyberspace.'

39 Mickey Meece, Who's the Boss, You or Your Gadget?, N.Y. Times (Feb. 5, 2011), available at http://www.nytimes.com/ 2011/02/06/business/06limits.html?pagewanted=all (last visited on Apr. 30, 2012).

40 Robert Cyran, A Patent Fever Over Smartphones, N.Y. TIMES (Jul. 31, 2011), available at http://www.nytimes.com/ 2011/08/01/business/a-patent-fever-over-smartphones.html (last visited on Apr. 30, 2012).

41 Supra note 25.
} 
administrative and legal proceedings. This is because patent right enforcement in general and patent litigation in particular have been considered to be matters of domestic concern. 42 When it comes to patents, there is no globalized enforcement system because a patent is by itself local in nature. 43

\section{Digital Divide}

Moreover, given the new capabilities of the ever-improving digital technologies, their availability or non-availability has significant consequences on the daily lives of people.44 Access to these devices is critical to keeping up with the new social paradigm shift. The term, 'digital divide' refers to the social gap between those who have access to new products and those who do not. 45 How many times have we been frustrated by the slow and sporadic internet connection we experience in certain countries? Such a digital divide can emerge not only at the individual level, but also at the national level; a State's overall limitation of access to these items could put the general public at a significant disadvantage in terms of economic development. 46 In other words, the divide can take place both domestically and internationally. 47

The patent clash between dominant digital corporations is designed to completely exclude the competitor's products from the domestic market of a country.48 By nature, the patent disputes are all-or-nothing games. 49 When two rival corporations respectively initiate proceedings in multiple countries at the same time under a tit-fortat strategy, the two corporations will have possibly won in some jurisdictions and lost

42 See World Intellectual Property Organization ("WIPO"), Frequently Asked Question, available at http://www.wipo.int/patentscope/en/patents_faq.html\#who_grants (last visited on Apr. 30, 2012). It reads: "At present, no world patents or international patents exist. In general, an application for a patent must be filed, and a patent shall be granted and enforced, in each country in which you seek patent protection for your invention, in accordance with the law of that country."

43 In fact, the WIPO provides the list of all municipal laws relating to the patent application and patent enforcement. See the WIPO website, available at http://www.wipo.int/directory/en/urls.jsp (last visited on Apr. 30, 2012); WIPO, WIPO Guide to Using Patent Information, WIPO Publication No. L434/3 (E), at 4 (2010).

44 One observer opined that: "The smartphone industry would threaten the automobile industry as more teenagers prefer to have smartphones first over cars." See Nick Bilton, Disruptions: For Teenagers, a Car or a Smartphone?, N.Y. Times (Nov. 20, 2011), available at http://bits.blogs.nytimes.com/2011/11/20/a-teenage-question-a-car-or-asmartphone/ (last visited on Apr. 30, 2012).

45 Susan Crawford, The New Digital Divide, N.Y. Times (Dec. 3, 2001), available at http://www.nytimes.com/2011/ 12/04/opinion/sunday/internet-access-and-the-new-divide.html?pagewanted=all (last visited on Apr. 30, 2012).

46 Neil Munshi, Bharti Airtel Brings $4 G$ to India, Financial Times, (Apr. 11, 2012), available at http://blogs.ft.com/ beyond-brics/2012/04/11/bharti-airtel-brings-4g-to-india/\#axzz1seiH0ne2 (last visited on Apr. 30, 2012).

47 Paul Taylor, Divide between Tech-Savvy Countries Widens, Financial Times (Apr. 5, 2012), available at http://www.ft.com/intl/cms/s/0/29d0afa8-7e74-11e1-b009-00144feab49a.html\#axzz1semBoDyW (last visited on Apr. 30, 2012).

48 TRIPs Agreement arts. 41 \& 61 .

49 Id. 
in others. What ultimately emerges is the situation where the domestic markets of many countries are divided by the duopoly of the corporations along the territorial borderlines. Under these circumstances, importation or sales prohibitions of a key product in one country would impose the digital divide on the people of that country. As the society becomes further digitized and more wired, failure to ensure access to preferred products, whether triggered by financial reasons or regulatory sanctions, will only serve to widen the digital divide. 50

Therefore, legal battles between digital giants carry immediate and significant effects for the lives of laymen. To the extent the IT products function as an important tool to connect to the world, inability to purchase such products would significantly affect the way people live their lives. 51 Such absence or inability would lead to a number of problems. First, people in a given jurisdiction would be deprived of choice when making a purchase. Second, a division of global digital markets following the contours of national boundaries may hamper the critical emergence and development of the global connection in cyber space. Since one of the primary purposes of digital development is to lessen territorial confinement and physical boundaries, it seems ironic that the litigation flooding the IT sector is maintaining or even strengthening territorial division.

\section{Chain Reaction in Multiple Jurisdictions}

The unique traits of IT corporations and digital products have put the ongoing patent disputes between Samsung and Apple in a new dimension. The omnipresence of the corporation in a single global market has prompted the two corporations to compete fiercely in every country. Under these circumstances, heated competition can easily escalate into litigation and engulf multiple jurisdictions very quickly. As competition in the single global market increases, absent a global patent forum, mobilization of respective domestic courts is inevitable.

This may explain the sudden flooding of patent disputes in the domestic courts of various countries. It basically comes down to an awkward situation where domestic courts of many countries are simultaneously mobilized to settle the disputes between the two private entities. Samsung and Apple are taking advantage of the legal

50 John Markoff, High-Tech Executives Urge Action on World's Digital Divide, N.Y. Times (Jul. 20, 2000), available at http://www.nytimes.com/2000/07/20/world/high-tech-executives-urge-action-on-world-s-digital-divide.html?gwh= FBC03D75E8ECDD5AC42255B3DD496F31 (last visited on Apr. 30, 2012).

51 One expert opined that: "The legal battle between the two companies was not in the interest of the consumers as it might result in sales of products being affected, and then arguably, it is the duty of the authorities to play a role in addressing the issue." See BBC News, supra note 5. 
apparatus of the countries in which they conduct their businesses.

\section{Effect on International Legal Jurisprudence regarding State Jurisdiction}

Jurisdiction has been an important topic of international law. The jurisdictional discussions of international law, however, have mainly dealt with situations where a 'single' dispute is lodged at a court of a 'single' country. Concurrent litigation in multiple jurisdictions, as being observed at present, has been hardly been discussed by scholars of international law. For better or worse, the Samsung-Apple disputes are now raising this issue. It is in this context that sometimes extraterritorial application of jurisdiction, which is the assertion of a State's sovereign authority beyond its borders, 52 stokes controversies. Traditionally, a State's legal power is limited to disputes with its own borders. The concept of extraterritorial jurisdiction was also perceived to be the violation of State sovereignty, which is one of the most fundamental principles of international law.

\section{Jurisdiction under International Law}

Jurisdiction under international law can be defined as a "sovereign State's power and authority over persons, property and events." 53 Jurisdiction then is usually divided into two categories: prescriptive jurisdiction and enforcement jurisdiction. 54 The former is a State's sovereign authority to prescribe what is legal or illegal,55 while the latter is the power to enforce the law as prescribed.56 Prescriptive jurisdiction then includes five bases: (1) Territorial Principle; (2) Nationality Principle; (3) Passive Nationality Principle; (4) Protective Principle; and (5) Universality Principle.57 A State can choose one or multiple jurisdictional principle(s) out of the five bases depending upon the situation it attempts to regulate. 58 At the same time, it should be noted that jurisdictional principles under international law are basically 'permissive rules' rather than 'obligatory rules.' 59 As such, in most cases, it means that a State may exercise jurisdiction in a particular

\footnotetext{
52 Justin Desautels-Stein, Extraterritoriality, Antitrust and the Pragmatist Style, 22 Emory INT' L L. REv. 499 (2008).

53 Antonio Cassese, International LaW 49-50 (2nd ed. 2005). See also Murphy, supra note 18, at 253-256; Martin Dixon \& Robert McCorquodale, Cases \& Materials on International LaW 268-269 (4th ed. 2003); ReStatement (ThiRd) of Foreign ReLations LaW of the U.S. [ReStatement] § 401 (1987). 
situation or refrain from exercising its jurisdiction. 60

International law recognizes 'jurisdiction' as lying in the hands of individual States. Jurisdiction is permitted as long as it is based on the principles set forth in international law (as for the prescriptive jurisdiction) and enforced within its territory (as for the enforcement jurisdiction). Indeed, the permissive nature of jurisdictional rules under international law may underscore a possibility that States involved in an event sharing a common nexus can pursue coordination of competing or overlapping jurisdictions among them, unless their domestic interest is seriously undermined.

\section{Jurisdiction as an Inherently Municipal Issue}

Jurisdictional discussions under international law have been inherently confined within national boundaries. It is true that prescriptive jurisdiction can sometimes extend beyond borders, but enforcement jurisdiction, which is directly relevant to domestic patent litigation, is always restricted to the territorial boundaries. ${ }^{61}$ As far as the enforcement aspect is concerned, all these discussions are fragmented and compartmentalized under international law; that is, judicial proceedings take place in each State with all different outcomes, the effect of which is enforceable only within the territory of each State. The discussions rarely go beyond the national boundaries so as to take into consideration existence or exercise of jurisdiction by other States.

This fragmented approach may not adequately address the fast globalization and exploding inter-State transactions that we are now observing. ${ }^{62}$ Especially, the traditional concept of the national borders is almost meaningless with the development of information technology. A global convergence is taking place in all sectors; the trend

This situation is vividly exemplified by the recent refusal of many countries to punish Somali pirates. Several governments released the apprehended pirates because of the logistical and legal obstacles that would have ensued in the prosecution of the pirates in their home countries. The US Secretary of State Rice observed in her declaration of 16 December 2008 before the Security Council: "the international community already has sufficient legal authority and available mechanisms to apprehend and prosecute pirates, but sometimes the political will and the coordination have not been there to do so" (S/PV.6046, at 10). See also Craig Whitlock, Lack of Prosecution Poses Challenge for Foreign Navies that Capture Pirates, WASH. PosT (May 24, 2010), at A8, available at http://www.washingtonpost.com/ wpdyn/content/article/2010/05/23/AR2010052303893.html (last visited on Apr. 30, 2012); Eugene Kontorovich, International Legal Responses to Piracy off the Coast of Somalia, Am. Soc'y InT'L L. Insights (Feb. 6, 2009), available at http://www.asil.org/insights090206.cfm; Gerry J. Gilmore, Kenyan Government Agrees to Try Pirates Seized by U.S. Forces, AM. Forces Press Serv. (Jan. 29, 2009), available at http://www.defense.gov/news/ newsarticle.aspx?id=52871 (all last visited on Apr. 30, 2012). Sometimes there may be instances where a State must exercise jurisdiction because of the requirements under its domestic law.

61 Id.

62 For more information, see Chad Haddal \& Michael Garcia, Border Security: Barriers along the U.S. International Border, CRS Report RL33659, available at http://www.fas.org/sgp/crs/homesec/RL33659.pdf (last visited on Apr. 30, 2012). 
is noticeable in the field of information technology and cyber space activities. 63 Thus, although a fragmented approach to jurisdiction has worked fine with traditional issues and events occurring inside the national boundaries, 64 it may not work with something transcending geographical boundaries. Fragmented jurisdictions may not be able to cope with converged activities taking place on a global scale, which have surfaced in other areas such as telecommunications and the internet. However, they are still tied to jurisdictional limitations one way or another. While the previous convergence can be considered to be only geographically limited and temporally sporadic, the recent convergence regarding the new digital products is arguably ubiquitous and constant. The lives of consumers have now been tightly integrated into this converged dimension.

The tension between fragmentation and convergence is especially noticeable in the patent litigation of digital products. Even as digital products become more global, patent law still remains within the territorial limits of States, 65 as registration and enforcement of patents are still exclusively reserved to the hands of individual States.66

Jurisdictional principles have generally evolved in a way that expands the jurisdiction of individual States, as best evidenced by the effects doctrine. 67 The expansion has mainly strengthened the fragmentation of national jurisdictions of individual States. The fast emerging situation, however, would arguably require adjustment of existing jurisdictional principles to keep up with the introduction of unprecedented spread of borderless activities.

\section{In Search of a New Paradigm}

In summary, the recent clash between Samsung and Apple showcases the limitations of the existing paradigm regulating the leading MNCs with dominant power in the global market. The traditional concept of jurisdiction may be unable to effectively address the concerns of the States and corporations. An argument can be made that the situation requires consideration of exploring a new paradigm to be applied in this instance.

\footnotetext{
63 David Johnson \& David Post, Law and Borders: The Rise of Law in Cyberspace, 48 StAN. L. Rev. 1370 (1996).

64 See Jurisdictional Immunities of the State (F.R.G. v. Italy), Judgment, 2012 I.C.J $\uparrow 57$ (Feb. 3, 2012).

65 Raquel Xalabarder, Copyright: Choice of Law and Jurisdiction in the Digital Age, 8 ANN. SuRv. INT' L \& Comp. L. 79, 80 (2002).

66 TRIPs Agreement, Pt. II, sec. 5 .

67 See United States v. Aluminum Co. of Am. Case, 148 F.2d 416 (2d Cir. 1945) (establishing an effects nexus for violations of U.S. antitrust laws); Timberland Lumber Co. v. Bank of Am. Case, 549 F.2d 597 (9th Cir. 1976).
} 


\section{A. Regulation of the MNCs' Abusive Utilization of Jurisdictional Rules}

The first issue is to regulate the abusive utilization of jurisdictional rules under international law. An 'inconvenient truth' is that some MNCs now seem more influential than not a few sovereign States. 68 Their global influence can be felt in many respects. The fact that they can simultaneously finance and manage numerous proceedings at a dozen or so States indicates that the legal sector is no exception. The recent phenomenon shows that these digital giants are willing to go to the courts of many countries so as to achieve their business goals. Put differently, these corporations now aggressively utilize the jurisdictions of various States for the purpose of maintaining their competitive edge in the global market.

Jurisdictional concepts have been developed to ensure that a sovereign State can exercise its authority over an event or a person. ${ }^{69}$ This situation, however, seems to be the other way around. When corporations voluntarily come to selected States to further their authority over an event or a person, the State judiciary becomes a pawn in the game between those corporations. This phenomenon is more serious than forumshopping, which is a serious problem in and of itself; rather, it could be called 'forummobilizing.' The present jurisdictional principles under international law, however, apparently fail to provide sufficient jurisprudence to regulate the behavior of the MNCs in this context. If this phenomenon is left unchecked, the dominance of digital corporations may rise to the level of threatening the basic framework of the Statecentered international community. If the international community develops jurisprudence that can identify and restrict abusive utilization of multiple jurisdictions by the MNCs, this would constitute a meaningful first step for international law in adopting a legal framework to regulate their behavior.

\section{B. Mismatch between Jurisdictional Rules and the Digital World}

The second issue is to recognize the apparent mismatch between the jurisdictional rules and the new digital world, and find ways to bridge the gap. So far the discussions on jurisdictional issues in the context of the digital world have mainly focused on who has

68 Beth Stephens, The Amorality of Profit: Transnational Corporations and Human Rights, 20 BERKELEY J. INT' L L. 47-48 (2002). See also John Ruggie, Protect, Respect and Remedy: A Framework for Business and Human Rights, Report of the Special Representative of the Secretary-General of the United Nations 3 (2008).

69 See Cassese, supra note 53, at 49-50; Murphy, supra note 18, at 253-256; Dixon \& McCorquodale, supra note 53, at 268-269; ReStatement, supra note 53. 
jurisdiction over cyberspace. ${ }^{70}$ However, these discussions have not been directed at dealing with the mismatch between the traditional rules and fast changing reality in the new digital age. The mismatch can be found in the following two aspects.

\section{Global Competition with Local Jurisdiction}

The conventional framework of jurisdiction will continue to work if litigation takes place in a single or relatively few State(s). ${ }^{71}$ The purpose of such litigation would be to address local competition through a local court. Such symmetry, however, is lost in the case of the Samsung vs. Apple disputes. Here, lawsuits have been lodged in a large number of major jurisdictions to address a problem which is essentially related to a single global market. Regardless of the number of separate domestic jurisdictions being mobilized, the nature of the jurisdiction still remains local, because a concept such as transnational jurisdiction or global jurisdiction does not exist in general or with respect to patent issues in particular. Thus, we have a ill-matched situation of 'global' competition with 'local' jurisdiction.

Such a situation may cause structural problems. As the objective of the litigation is to address global competition, a chain reaction of lawsuits in as many jurisdictions as possible seems almost inevitable. Due to the unique exclusionary effect of patent disputes, consumers end up suffering in the end.

The mismatch also makes it more difficult to offer a final resolution of the dispute. Although essentially the same legal claims are involved in each case, the outcome of the legal proceedings in a large number of jurisdictions may all differ following the technicalities and small factual variances. When these outcomes are reviewed on an individual basis, there would be no problem. However, when one takes a step back, a different picture emerges. Essentially each case raises the same issues, but the results rendered very depending on the State. As seen in medieval feudalism, a victor may turn out to be the ruler of a fief, but a neighboring domain will be ruled by another lord. Under these circumstances, the necessity to address the mismatch appears obvious.

\section{Global Influence with Local Responsibility}

Another kind of mismatch arises in the form of global influence with local

70 See Sanjay Mody, National Cyberspace Regulation: Unbundling the Concept of Jurisdiction, 37 STAN. J. INT' L L. 365 (2001); Ronald Brand, Intellectual Property, Electronic Commerce and the Preliminary Draft Hague Jurisdiction and Judgments Convention, 62 U. PITT. L. Rev. 581 (2001); Tyler Anderson, An Analysis of Personal Jurisdiction and Conflict of Laws in the Context of Electronically Formed Contracts, 37 IDAHO L. REv. 477 (2001); Melissa Cantrell, The Taming of E-Health: Asserting U.S. Jurisdiction over Foreign and Domestic Websites, 103 W. VA. L. Rev. 573 (2001); Susan Exon, A New Shoe Is Needed to Walk Through Cyberspace Jurisdiction, 11 AlB. L. J. ScI. \& TeCH. 1 (2000).

71 Reinisch, supra note 23 , at 88-89. 
responsibility. Corporations like Samsung and Apple exert and enjoy 'global' influence. But they are liable for the patent violation only at a 'local' level. The mismatch of dimension between influence and responsibility would not be able to guide the digital giants in the appropriate direction as the market and consumers demand.

This mismatch would seem to intensify in the future because of the specific obligations imposed by the WTO's TRIPs. The TRIPs sets forth detailed obligations for all member States concerning patent protection. ${ }^{72}$ The focus of the TRIPs is to impose specific obligations on each member to effectively enforce its 'domestic' IP laws including patents. 73 Some countries even enter into agreements to further enhance the 'domestic' enforcement function among like-minded countries. ${ }^{74}$ All of these enforcement covenants are designed to operate within the jurisdictional principles of each country.75 Then, the enforcement of the domestic laws and regulations may vary significantly, even with similar substantive provisions, as a result of different cultural and social backgrounds among the States. ${ }^{76}$ A different level of domestic enforcement would lead to that of responsibility for the entities involved. Consequently, the level of responsibility that these corporations may assume would not square with the level of influence they exert in the global market.

\section{Addressing the Mismatch}

The next issue is how to address the perceived mismatch. Is there a way to adjust

72 TRIPs Agreement arts. 27-34.

73 Id. arts. $41 \& 61$. The official title of this dispute is "China - Measures Affecting the Protection and Enforcement of Intellectual Property Rights (DS362)." In this controversial dispute, the United States alleged that the criminal enforcement system of China regarding violations of intellectual property rights failed to carry out China's obligation under the TRIPs, most notably Article 61 of the agreement. China, in turn, argued that each member has considerable leeway in formulating and administering its own criminal enforcement mechanism under international law and the TRIPs, and that the TRIPs do not allow intervention by a State with an issue that is reserved to a purely domestic domain of another State.

74 For instance, Australia, Canada, the European Union, Korea, Japan, New Zealand, Singapore, Switzerland and the United States concluded the Anti-Counterfeiting Trade Agreement ("ACTA") on October 13, 2011 to enhance the level of the enforcement for the IPRs within their respective jurisdictions beyond the level required under the TRIPs. See WTO, Enforcement of Intellectual Property Rights, IP/C/W/563 (Oct. 17, 2011), available at http://www.wto.org/english/res_e/res_e.htm (last visited on Apr. 30, 2012).

75 For instance, Article 41, paragraph 4 of the TRIPs stipulates as follows:

4. Parties to a proceeding shall have an opportunity for review by a judicial authority of final administrative decisions and, subject to jurisdictional provisions in a Member's law concerning the importance of a case, of at least the legal aspects of initial judicial decisions on the merits of a case. However, there shall be no obligation to provide an opportunity for review of acquittals in criminal cases.

76 See Panal Report, Japan-Measures Affecting Consumer Photographic Film and Paper, $\uparrow 10.43-10.46$, WT/DS44/R (Apr. 22, 1998). 
jurisdictional principles or to coordinate jurisdictions being exercised by multiple States over an issue that is the same in essence or at its core?

As the exercise of jurisdiction is the most vivid expression of national sovereignty, one cannot certainly force a country to exercise or give up its jurisdiction.77 Such an action would constitute violation of international law as intervening into other nation's domestic affairs. ${ }^{78}$ Exercise or non-exercise of jurisdiction is a deliberate choice to be made by an individual country in a particular situation. From this basic principle, there will be an inherent limitation in exploring ways to adjust State jurisdiction in this regard. ${ }^{79}$ Amending the current jurisdictional rules or creating a new one will be thus a quite difficult task to achieve. In an effort to amend the existing jurisdictional rules, e.g., one may advocate the concept of global jurisdiction, referring to jurisdiction over a single global market as a new form of prescriptive jurisdiction under international law. Under this scheme, a MNC may select one jurisdiction to raise patent infringement claims relating to its competition in a single global market. Once a jurisdiction is selected and a claim is filed, the corporation is precluded from submitting the same claim to other jurisdictions. A fundamental overhaul like this, however, would cause much criticism and invite delay. So, it may be appropriate to explore ways to address the mismatch problem in a manner that does not significantly deviate from the present framework. By way of example, the following approaches could be contemplated in this regard.

\section{Exploring Forum Non Conveniens Jurisprudence}

First, there is some room to maneuver for an individual State to address the problem. The critical prerequisite to pursue this alternative is for the States to be appraised by the problems of the present situation. A consensus should be formed that if this situation remains unattended, it is the international community as a whole that stands to lose as a result of the explosion of duplicative and abusive lawsuits. Assuming that a critical mass of consensus for concerted action emerges, individual States may adopt a course of action in which it refrains from exercising unnecessary or duplicative jurisdiction in a situation like the Samsung-Apple dispute. As noted above, the principle of jurisdiction under international law is simply a permissive rule and non-exercise of jurisdiction, even though a jurisdictional basis is somehow established, does not necessarily constitute violation of international law. 80 In many instances, actually, we observe States

77 Supra note 69.

78 Cassese, supra note 53, at 53-54. See also Gerhard Glahn \& James TaulbeE, LaW Among Nations: An Introduction

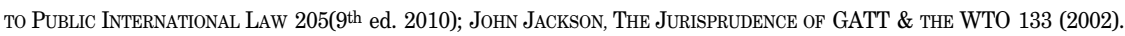

79 Stephen Krasner, Sovereignty: ORGanized Hypocrisy 20-25 (1999).

80 Supra note 69. 
refusing to exercise jurisdiction despite the plea of other countries, if doing so would harm its national interest. 81

Consequently, it seems not to be a specific obstacle that hinders a State from being more cautious and prudential when it comes to exercising jurisdiction in situations involving particular types of disputes. Non-exercise of jurisdiction could thus become an issue under respective domestic law, if there is one which mandates exercise of such jurisdiction.

This prudential approach may be in line with the doctrine of forum non conveniens, which is designed to leave a dispute within the jurisdiction that can best handle it. ${ }^{82}$ The patent infringement claims that are raised in the Samsung vs. Apple disputes involve essentially the same underlying factual issues. Among a large number of States that can or are requested to exercise jurisdiction over the same issues, there may be one or several jurisdictions that could best hear and handle the dispute. If so, other States might consider applying the forum non conveniens jurisprudence. 83 In fact, in recent international litigation, international courts tend to underscore the importance of putting substance over form. 84 In light of this rationale, as long as a sufficient nexus,

81 Many countries have refrained from exercising jurisdiction over pirates captured in Somalia because of the financial and logistical burden in detaining and trying the pirates.

82 The doctrine of forum non conveniens permits a U.S. court to decline to exercise its judicial jurisdiction if the court would be a seriously inconvenient forum and if an adequate alternative forum exists. See GARY BoRn \& DAVID Westin, InTERnATIONAL Civil Litigation In United STATES Courts 275 (2nd ed. 1994). Although a court may have in personam or in rem jurisdiction, it may choose not to assume that jurisdiction. The common way that courts do so in international disputes is by invoking the doctrine of forum non conveniens. In essence, this allows a court to decline to hear a case that can also be heard elsewhere if it is either inconvenient or unfair for the forum court to do so. In determining this, a court will consider: (1) the private interests of the parties (i.e., the ease and cost of access to documents and witnesses); and (2) the public interests of the forum (i.e., the interests of the forum in the outcome of the dispute, the burden on the court to hear the case, and whether another forum has a much greater interest in the outcome of the dispute). See Gulf Oil Corp. v. Gilbert Case, 330 U.S. 501, 508-509 (1947).

83 In addition, the Court confirmed the District Court's assertion that, although there is ordinarily a strong presumption in favor of the plaintiff's choice of forum, the presumption applies with less force when the plaintiff is foreign. See Piper Aircraft Co. v. Reyno Case, 454 US 235, 255 (1981).

84 This approach is also supported by the Appellate Body precedents. In U.S.Zeroing (EC) (21.5), the Appellate Body explicitly upheld the nexus based approach while rejecting a "formalistic reliance on the date of issuance [of the individual measures]." It held that:

The relevant inquiry was whether the subsequent reviews, despite the fact that they were issued before the adoption of the recommendations and rulings of the DSB, still bore a sufficiently close nexus, in terms of nature, effects, and timing, with those recommendations and rulings...

See Appellate Body Report, United States - Laws, Regulations and Methodology for Calculating Dumping Margins ("Zeroing"): Recourse to Article 21.5 of the DSU by the European Communities @ 226, WT/DS294/AB/RW (May 14, 2009). Also, in a recent dispute, a WTO panel adopted a similar approach. The panel in U.S.-Tuna II Case stated in recent finding that it "must therefore consider whether these various instruments taken together may be described as constituting the measures before us." See Panel Report, United States - Measures Concerning the Importation, Marketing and Sale of Tuna and Tuna Products 97.16 WT/DS381/R (Sept. 11, 2011) The panel also Stated that the question it must consider "is whether it is appropriate to consider these measures jointly in our 
both legally and factually, is confirmed to pronounce an authoritative decision in a dispute involving many jurisdictions, the court of the State might attempt to hear the dispute and render a judgment.

\section{Diluting All-or-Nothing Judgment}

If States can amend or enact domestic laws and regulations to alleviate the winner-takeall outcome, that would play an important role in addressing the perceived mismatch. As discussed, an all-or-nothing judgment would further expedite the fragmentation of the global markets along a State's borders, which does not reflect the reality of single global market competition. States could discuss introducing domestic legal mechanism where a judgment or remedy less stringent than a total exclusion from the market can be rendered. The problem here, however, is that the IPR infringement often requires such a drastic measure. 85 The basic approach adopted by the relevant IPR conventions including the TRIPS may be revisited in the future to tackle this problem.

\section{Expanding the MNC Code of Conduct}

There are also some areas in which corporations themselves can take some remedial action. As shown in the example of the UN Compact, the MNCs may pledge themselves to refrain from abusive exploitation of jurisdictions of many countries in a retaliatory effort to secure dominance in the global market. As noted above, the MNCs have adopted codes of conduct in certain areas such as human rights or labor standards. Although these codes of conduct are voluntary and do not involve legal obligations, its long-term impact as soft law is still meaningful. 86 Thus, the MNCs may also consider subscribing to voluntary regulation to denounce frivolous or unnecessary litigation whose main purpose is to achieve commercial advantage in the global market, as opposed to seeking a good faith remedy for injuries suffered. Although it may be difficult to discern what constitutes good faith or not, it would at least provide a meaningful first step to guide the MNCs in an appropriate direction.

In fact, this pledge of the MNCs may apply not only to lawsuits between themselves, but also vis-à-vis States. It is becoming a real obstacle for many governments to deal with the lawsuits initiated by the MNCs operating or investing within their territories. The FTAs and the BITs have enabled the MNCs to bring legal proceedings at an international tribunal against foreign governments. However, these proceedings are

\footnotetext{
analysis of Mexico's claims, and make findings based on their combined operation, rather than on the basis of each individual measure separately. See Panel Report, United States - Measures Concerning the Importation, Marketing and Sale of Tuna and Tuna Products 9 7.21. WT/DS381/R (Sept. 11, 2011).

85 TRIPs Agreement art. 61.

86 See generally supra note 23.
} 
sometimes utilized for trivial purposes. 87 From this perspective, the suggested pledge might be meaningful for many purposes under the present circumstances of the international community. The UN-led discussions on the CSR, however, have not had an opportunity to consider this issue thus far. 88

\section{Adopting a Treaty Harmonizing Jurisdictional Overlap}

As discussed above, the traditional jurisdictional rules are designed to lock the dominant digital MNCs in a web of endless domestic lawsuits. One of the solutions to break this web would be for the international community to consider the possibility of adopting a treaty harmonizing respective jurisdictions in either cyberspace or examining patent disputes. In the substantive area of patent law, actually, the efforts to achieve harmonization among the patent laws of respective countries are already being made. 89 In addition to the substantive provisions, the harmonization of jurisdictional rules can be also contemplated in this regard. Harmonization is warranted because, to the extent the domestic laws and judicial proceedings reflect different cultures and civilizations, the fragmentation of the judicial proceedings for an essentially global issue could lead to unexpected and unnerving tension. 90

Through such a treaty, States may assume obligations to adjust their domestic laws, regulations and jurisprudence towards enhancing the harmonization with those of other States. One may recall the fact that national courts, though with many limitations, have played an important role for the development and refinement of international law. 91 In spite of a different context, the problem caused by fragmentation has attracted international attention in other international adjudicatory proceedings. 92 This trend may

87 See Phoenix Action, Ltd. v. The Czech Republic ICSID Case, No. ARB/06/5 at 9-12 (2009).

88 For instance, the UN Global Compact focuses on 9 sectors relating to the MNCs, including: Human Rights, Labour, Environment, Anti-Corruption, Business and Peace, Financial Markets, Business for Development, UN-Business Partnerships, Supply Chain Sustainability. Apparently, discussions on the abusive utilization of fragmented domestic jurisdiction of multiple countries are not included in the project list. See the UN Global Compact website available at http://www.unglobalcompact.org/Issues/index.html (last visited on Apr. 30, 2012).

89 Hector Macqueen et al., Contemporary Intellectual Property: LaW and Policy 385-386 (2008); WIPO, Draft Substantive Patent Law Treaty, available at http://www.wipo.int/patent-law/en/harmonization.htm (last visited on Apr. 30, 2012).

90 Samule Huntington, The Clash of Civilizations and the Remaking of World Order 321 (1996).

91 Murphy, supra note 18, at 147-150.

92 In fact, the non-uniform administration of judicial proceedings has been a controversial issue at the WTO. Article X:3(a) of the GATT 1994 sets forth obligations for each WTO Member to adopt a uniform judicial proceedings. In EC-Selected Customs Matters Case, the Appellate Body of the WTO had an opportunity to review this issue. In the underlying panel proceeding, the panel examined whether the EC failed to provide for the prompt review and correction of its customs administrative actions. Complainants argued that under the EC system, the tribunals of the twenty-five member States could reach different decisions concerning the same practice of the EC customs 
further evidence the importance of enhancing harmonization rather than fragmentation.

\section{Relevant Examples}

\section{a. EU's Aviation Carbon Tax Imposition}

A recent jurisdictional dispute among major countries raises the necessity to enhance harmonization of jurisdiction between concerned States. This dispute concerns the EU's imposition of aviation taxes to curb greenhouse gas emissions. Starting from January 1 , 2012, the EU finally included the aviation industry in its $\mathrm{CO}_{2}$ Emission Trading System and started to impose extra taxes on airliners. 93 Actual payments will not take place until 2013, but the system has been already implemented. ${ }^{94}$ All foreign airlines are also subject to this new regulation as long as their aircrafts land or take off using airports in EU countries. 95 Violators will be punished with hefty fines. 96

Many countries are affected by this new measure including the United States, China, India and Russia. These countries have criticized the EU law harshly. ${ }^{97}$ The criticism is largely based on the nature of the measure as extraterritorial application of a domestic law. 98 The measure covers all foreign aircrafts even if a major portion of a flight occurs outside the airspace of the EU.99 Other countries argue that one country's unilateral pursuit of a solution may fail to find an ultimate solution and the real solution can only be found at discussions and coordination through an international forum such as

agencies. In other words, the EC's review tribunals or procedures consist of the courts of the various member States, each of which is empowered to issue decisions that govern the practice only of the agency in its respective member State. A decision from a tribunal of a member State does not bind customs agencies of the other 24 member States. As one would read the language of Article X:3(b) of GATT 1994, the EC is obligated to provide for a EC-wide review mechanism which binds all the customs agencies within its borders and which guarantees the same decision for the same type of customs practices. It is clear that the EC failed to do so, and the failure constitutes violation of Article X:3(b) of GATT 1994. The Appellate Body thus opined that:

In order to find that an administrative process has led to non-uniform administration of a measure under Article

$\mathrm{X}: 3(\mathrm{a})$, a panel cannot merely rely on identifying the features of an administrative process that it may view as non-

uniform; a panel must go further and undertake an analysis to determine whether those features of the administrative

process necessarily lead to non-uniform administration of a legal instrument of the kind described in Article X:1.

See Appellate Body Report, European Communities - Selected Customs Matters, ๆ 239, WT/DS315/AB/R (Nov. 13, 2006).

93 Jane Leggett et al., Aviation and the European Union's Emission Trading Scheme, in U.S. CongREsSIONAL RESEARCH SERvice 12 (2012). See also Alister Doyle, U.S. Seeks Exemption to EU Aviation CO2 Plan, REUTERS, available at http://www.reuters.com/article/2011/06/22/us-carbon-airlines-idUSTRE75K4RA20110622 (last visited on Apr. 30, 2012).

94 Leggett et al., id. at 9.

95 Id. at 12.

96 Id. at 10.

97 Id. at 28-29.

98 Id. at 25, 28-29.

99 Id. 


\section{International Civil Aviation Organization ("ICAO”).100}

The rift wrought by the EU measure exemplifies the importance of coordination among States in dealing with 'global' activities involving multiple countries' jurisdictions. It supports the proposition that a 'global' problem under individual jurisdictions can only be properly addressed by a global solution. At the core of all these phenomena lies the tension between the national sovereignty (including jurisdiction) and globalization. The more critical task now seems to attain a coordinated effort between the States.

\section{b. Long-Arm Jurisdiction of Antitrust Laws}

Another relevant example in this regard is the gradual accumulation of consensus among States regarding the change of jurisdictional principle for antitrust laws. At first, quite a few countries criticized the long-arm jurisdiction of the U.S. antitrust laws as a violation of international law. 101 The criticism was triggered by the extraterritorial application of its U.S. antitrust law by U.S. courts for action taking place in another country, which violated one of the most fundamental tenets of territorial sovereignty. 102 In spite of this criticism, other countries have now adopted their own antitrust statutes modeled after the U.S. law.103 Although this expansive application of the jurisdictional principle has been gradually justified by the so-called 'effect doctrine,' the increasing acceptance of the new jurisdictional concept has been arguably prompted not by the advent of a new theory, but by the changing reality that requires such expansive application of jurisdiction to price-fixing activities on a global scale. This shows that at least in the area of antitrust law a new jurisdictional principle has gradually taken root in the international community permitting long-arm jurisdiction of antitrust regulation. 104 An attempt to address the jurisdictional problems in the new digital age

100 Harry Suhartono \& David Fogarty, EU Aviation Carbon Tax Fuels Concerns, May Go to U.N, ReUTERS, available at http://www.reuters.com/article/2012/02/13/uk-airshow-idUSLNE81C00W20120213 (last visited on Apr. 30, 2012).

101 For international conflicts caused by extraterritorial enforcement of the U.S. antitrust laws and the resulting foreign retaliatory response, see generally Seung Wha Chang, Extraterritorial Application of U.S. Antitrust Laws to Other Pacific Countries; Proposed Bilateral Agreements for Resolving International Conflicts within the Pacific Community, 16 Hastings InT'L \& Comp. L. Rev. 295 (1993). In this case, the Japanese government submitted an amicus brief stressing that the U.S. had violated international law and Japanese sovereignty. See Chad Stockel, Sherman's March on Japan: U.S. v. Nippon Paper and the Extraterritorial Reach of Criminal Antitrust Law, 9 TRANSNAT'L L. \& ConTEMP. PROBS. 399, 406 (1999).

102 Born \& Westin, supra note 82 , at 601.

103 For Japanese example of retaliatory legislation, see Chang, supra note 101, at 301-303. The European Court of Justice also endorsed extraterritorial application of antitrust laws. See Ahlstrom v. Commission Case, 1988 E.C.R.519, 4 C.M. L.R. 901 (1988).

104 Extraterritorial enforcement of antitrust and competition laws has become routine in both the United States and the European Union. Enforcement authorities on both sides of the Atlantic vigorously enforce their competition laws 
may also be able to garner gradual support, if the market demands such a change.105

\section{Conclusion}

The impact of rapid globalization has been recognized in many areas. The surge of mega corporations has made this situation ever more visible and phenomenal. These corporations exist in multiple jurisdictions concurrently, exerting significant influence over the fate of ordinary people. In some instances, these companies' power and influence dwarf the sovereign States in which they operate. Simultaneously, we are now experiencing unprecedented digitization in our daily lives.

The combination of globalization and unprecedented digitization presents us with a new set of questions and tasks. The recent patent disputes between Samsung and Apple spanning over a large number of jurisdictions offer an interesting portrait of what needs to be handled. One of the critical questions and tasks in this respect is the apparent mismatch between the rules of jurisdiction under international law and the actual competition in the global marketplace.

These two digital giants compete in one single global digital equipment market. Their smartphones and tablet PCs are advertised and sold over the whole global market virtually at the same time and under the same conditions. To these two corporations, the territorial boundaries are as meaningless to their business models. Also, the advent of a digital society has given these companies unprecedented power and influence over individuals and societies. Their products are not merely a communication device, but rather a major infrastructure of the digital society. Corporations that provide key components of such infrastructure are destined to exercise a significant amount of influence. What we observe now is a new digital authority that targets one single global market, while exerting significant influence over our daily lives.

In accordance with this drastic change, the traditional notion of jurisdiction under international law is fragmented and compartmentalized. Each sovereign State possesses its own jurisdiction and exercises it within the confinement in its own territory. This jurisdictional canon would not pose a problem if the event causing the invocation of the jurisdiction happened within a domestic territory of a State alone or within the territories of a small number of States. The situation, however, is quite different when

against conduct outside their borders to protect their consumers and markets. See Joseph Griffin, Extraterritoriality in U.S. and E.U. Antitrust Enforcement, 67 AnTtTRust L. J. 159 (1999).

105 Stockel, supra note 101, at 417-418. 
the event at issue is taking place in a different dimension such as cyber space or a single global market like the smartphone market. Unfortunately, the traditional criteria used to allocate jurisdiction seems to be ill-fitted to respond to the new challenges unfolding. Unless this issue is addressed properly, the mismatch between the jurisdictional norms and the real market situation would exacerbate the problems in the future.

Without necessarily disrupting the present framework of jurisdiction under international law, the international community may be able to alleviate or avoid the current problems. Coordinating jurisdictions among multiple States through the application of forum non conveniens or introduction of domestic laws that can dilute an all-or-nothing outcome in patent litigations are good candidates to pursue in this respect. Another alternative in this regard is to adopt an international agreement dealing with harmonization of domestic jurisdictions when essentially involving the same issue or a single global market. Facilitating the adoption of voluntary codes of conduct for corporations to refrain from frivolous litigation will be still another significant alternative. The jurisdictional concepts of the analog age may now have to be changed to face with the issues of digital age. 